MSC 35G61

DOI: $10.14529 / \mathrm{mmp} 170110$

\title{
COMPUTATIONAL EXPERIMENT FOR A CLASS OF MATHEMATICAL MODELS OF MAGNETOHYDRODYNAMICS
}

A.O. Kondyukov, Novgorod State University, Velikiy Novgorod, Russian Federation, k.a.o_leksey999@mail.ru,

T.G. Sukacheva, Novgorod State University, Velikiy Novgorod, Russian Federation, tamara.sukacheva@novsu.ru,

S.I. Kadchenko, Nosov Magnitogorsk State Technical University, Magnitogorsk, Russian Federation, kadchenko@masu.ru,

L.S. Ryazanova, Nosov Magnitogorsk State Technical University, Magnitogorsk, Russian Federation, ryazanova@ranber.ru

The first initial-boundary value problem for the system modelling the motion of the incompressible viscoelastic Kelvin - Voigt fluid in the magnetic field of the Earth is investigated considering that the fluid is under external influence. The problem is studied under the assumption that the fluid is under different external influences depending not only on the coordinates of the point in space but on time too. In the framework of the theory of semi-linear Sobolev type equations the theorem of existence and uniqueness of the solution of the stated problem is proved.The solution itself is a quasi-stationary semitrajectory. The description of the problem's extended phase space is obtained.The results of the computainal experiment are presented.

Keywords: magnetohydrodynamics; Sobolev type equations; extended phase space; incompressible viscoelastic fluid; explicit one-step formulas of Runge - Kutta.

\section{Introduction}

Consider the first initial-boundary value problem for the system modeling the motion of the incompressible viscoelastic Kelvin - Voigt fluid in the magnetic field of the Earth

$$
\begin{gathered}
(1-\chi \triangle) v_{t}=\nu \triangle v-(v \cdot \nabla) v-\frac{1}{\rho} \nabla p-2 \Omega \times v+\frac{1}{\rho \mu}(\nabla \times b) \times b+f^{1}, \\
\nabla v=0, \quad \nabla b=0, \quad b_{t}=\delta \triangle b+\nabla \times(v \times b)+f^{2}, \\
v(x, 0)=v_{0}(x), \quad b(x, 0)=b_{0}(x), \quad x \in D, \\
v(x, t)=0, \quad b(x, t)=0, \quad(x, t) \in \partial D \times R_{+} .
\end{gathered}
$$

Here vector-functions $v$ and $b$ correspond to velocity and magnetic induction respectively, $p$ is the pressure, vector-functions $f^{1}$ and $f^{2}$ correspond to external influences on the fluid and magnetic field respectively; $\Omega=\frac{1}{2} \nabla \times v$ is angular velocity, $\nabla$ is operator of Hamilton, $\delta$ is the magnetic viscosity, $\mu$ is the magnetic permeability, $\rho$ is the density, $D \subset R^{n}$ is the cylinder's domain with the boundary $\partial D$ of the class $C^{\infty}$. 
This work continues investigations of magnetohydrodynamics models which were started by the authors in [2,3]. Its distinctive feature is that there are vector-functions $f^{k}=\left(f_{1}^{k}, f_{2}^{k}, \ldots, f_{n}^{k}\right)$ in the right part of equations $(1)$.

The first initial-boundary value problem (1) - (3) is reduced to an abstract Cauchy problem for a semi-linear non-autonomous Sobolev type equation. On the base of the solvability theory of the indicated problem the theorem of existence and uniqueness of the solution of the stated problem is proved. The solution itself is a quasi-stationary semitrajectory. The description of the problem's extended phase space is obtained. The results of the computational experiment are represented. The results of part 1 are taken from [4], the results of part 2 are obtained on the base of the results [2]. During the computational experiment the methods of solution of the initial-boundary problem (1) - (3) are used. They were described in [3]. Also we used the software package [5].

\section{Semi-Linear Non-Autonomous Sobolev Type Equations}

Consider the Cauchy problem for the semi-linear non-stationary Sobolev-type equation

$$
u(0)=u_{0}, \quad L \dot{u}=M u+F(u)+f(t) .
$$

Here the operator $L \in \mathcal{L}(\mathcal{U} ; \mathcal{F})$, i.e. it is linear and continuous, ker $L \neq\{0\}$; the operator $M: \operatorname{dom} M \rightarrow \mathcal{F}$ is linear and closed and it is densely defined in $\mathcal{U}$, i.e. $M \in \mathcal{C l}(\mathcal{U} ; \mathcal{F})$; $\mathcal{U}$ and $\mathcal{F}$ are Banach spaces. Let $\mathcal{U}_{M}$ be the lineal $\operatorname{dom} M$ equipped with the norm of the graph $\left\|\left|\cdot\|\mid=\| M \cdot\left\|_{\mathcal{F}}+\right\| \cdot \|_{\mathcal{U}}\right.\right.$. We assume that $F \in \mathcal{C}^{\infty}\left(\mathcal{U}_{M} ; \mathcal{F}\right)$, and the function $f \in \mathcal{C}^{\infty}\left(\overline{\mathbb{R}}_{+} ; \mathcal{F}\right)$.

Consider (4) under condition that the operator $M$ is strongly $(L, p)$-sectorial [4]. It is well known that in this case a solution of this problem exists not for all $u_{0} \in \mathcal{U}_{M}$, and even if it exists it may be non-unique. So we introduce two definitions: the extended phase space and quasi-stationary semi-trajectory.

It is well known that if the operator $M$ is strongly $(L, p)$-sectorial, then $\mathcal{U}=\mathcal{U}^{0} \oplus \mathcal{U}^{1}$, $\mathcal{F}=\mathcal{F}^{0} \oplus \mathcal{F}^{1}$, where

$$
\mathcal{U}^{0}=\left\{\varphi \in \mathcal{U}: U^{t} \varphi=0 \exists t \in \mathbb{R}_{+}\right\}, \quad \mathcal{F}^{0}=\left\{\psi \in \mathcal{F}: F^{t} \psi=0 \exists t \in \mathbb{R}_{+}\right\}
$$

are the kernels, and

$$
\mathcal{U}^{1}=\left\{u \in \mathcal{U}: \lim _{t \rightarrow 0+} U^{t} u=u\right\}, \quad \mathcal{F}^{1}=\left\{f \in \mathcal{F}: \lim _{t \rightarrow 0+} F^{t} f=f\right\}
$$

are the images of the analytic solving semigroups $U^{t}=\frac{1}{2 \pi i} \int_{\Gamma} R_{\mu}^{L}(M) e^{\mu t} d \mu$, $F^{t}=\frac{1}{2 \pi i} \int_{\Gamma} L_{\mu}^{L}(M) e^{\mu t} d \mu\left(\Gamma \subset S_{\Theta, a}^{L}(M)\right.$ is a contour such that $\arg \mu \rightarrow \pm \Theta$ when $|\mu| \rightarrow+\infty)$ of the linear homogeneous equation $L \dot{u}=M u$. Let $L_{k}\left(M_{k}\right)$ be a restriction of the operator $L(M)$ on $\mathcal{U}^{k}\left(\mathcal{U}^{k} \cap \operatorname{dom} M\right), \quad k=0,1$. Then $L_{k}: \mathcal{U}^{k} \rightarrow \mathcal{F}^{k}$, $M_{k}: \mathcal{U}^{k} \cap \operatorname{dom} M \rightarrow \mathcal{F}^{k}, \quad k=0,1$; and restrictions $M_{0}$ and $L_{1}$ of the operators $M$ and $L$ on the spaces $\mathcal{U}^{0} \cap \operatorname{dom} M$ and $\mathcal{U}^{1}$ respectively are linear continuous operators and they have bounded inverse operators. 
So we reduce (4) to

$$
\begin{array}{ll}
R \dot{u}^{0}=u^{0}+G(u)+g(t), & u^{0}(0)=u_{0}^{0}, \\
\dot{u}^{1}=S u^{1}+H(u)+h(t), & u^{1}(0)=u_{0}^{1},
\end{array}
$$

where $u^{k} \in \mathcal{U}^{k}, \quad k=0,1, u=u^{0}+u^{1}$, operators $R=M_{0}^{-1} L_{0}, \quad S=L_{1}^{-1} M_{1}, \quad G=$ $M_{0}^{-1}(I-Q) F, H=L_{1}^{-1} Q F, g=M_{0}^{-1}(I-Q) f, \quad h=L_{1}^{-1} Q f$. Here $Q \in \mathcal{L}(F)(\equiv \mathcal{L}(F ; F))$ is the corresponding projector.

We study such quasi-stationary semi-trajectories of (4), for which $R \dot{u}^{0} \equiv 0$. Assume that the operator $R$ is $b i$-splitting, i.e. its kernel ker $R$ and image im $R$ are complemented in the space $\mathcal{U}$. Denote $\mathcal{U}^{00}=\operatorname{ker} R$, and $\mathcal{U}^{01}=\mathcal{U}^{0} \ominus \mathcal{U}^{00}$ is a complement of the subspace $\mathcal{U}^{00}$. Then the first equation of $(5)$ is reduced to the form $R \dot{u}^{01}=u^{00}+u^{01}+G(u)+g(t)$, where $u=u^{00}+u^{01}+u^{1}$.

Theorem 1. Let the operator $M$ be strongly $(L, p)$-sectorial, and the operator $R$ be bisplitting. Let there exist a quasi-stationary semi-trajectory $u=u(t)$ of equation (4). Then it satisfies the following relations

$$
0=u^{00}+u^{01}+G(u)+g(t), \quad u^{01}=\text { const. }
$$

It is known that if the operator $M$ is strongly $(L, p)$-sectorial then the operator $S$ is sectorial. So it generates an analytic semigroup on $\mathcal{U}^{1}$. Denote it as $\left\{U_{1}^{t}: t \geq 0\right\}$ because the operator $U_{1}^{t}$ in fact is a restriction of the operator $U^{t}$ on $\mathcal{U}^{1}$. The fact that $\mathcal{U}=\mathcal{U}^{0} \oplus \mathcal{U}^{1}$ shows that there exists a projector $P \in \mathcal{L}(\mathcal{U})$ corresponding to this splitting. It can be shown that $P \in \mathcal{L}\left(\mathcal{U}_{M}\right)$. Then the space $\mathcal{U}_{M}$ splits into the direct sum $\mathcal{U}_{M}=\mathcal{U}_{M}^{0} \oplus \mathcal{U}_{M}^{1}$ so that the embedding $\mathcal{U}_{M}^{k} \subset \mathcal{U}^{k}, \quad k=0,1$ is dense and continuous. Symbol $A_{v}^{\prime}$ denotes the Frechet derivative at $v \in \mathcal{V}$ of the operator $A$, defined on some Banach space $\mathcal{V}$.

Theorem 2. Let the operator $M$ be strongly $(L, p)$-sectorial, the operator $R$ be the bisplitting one, the operator $F \in \mathcal{C}^{\infty}\left(\mathcal{U}_{M} ; \mathcal{F}\right)$, the vector-function $f \in \mathcal{C}^{\infty}\left(\mathbb{R}_{+} ; \mathcal{F}\right)$. Let the following conditions be satisfied:

(i) $0=u_{0}^{01}+\left(I-P_{R}\right)\left(G\left(u^{00}+u_{0}^{01}+u^{1}\right)+g(t)\right)$ in the neighborhood $\mathcal{O}_{u_{0}} \subset \mathcal{U}_{M}$ of the point $u_{0}$;

(ii) the projector $P_{R} \in \mathcal{L}\left(\mathcal{U}_{M}^{0}\right)$, and the operator $I+P_{R} G_{u_{0}^{0}}^{\prime}: \mathcal{U}_{M}^{00} \rightarrow \mathcal{U}_{M}^{00}$ is the topological linear isomorphism $\left(\mathcal{U}_{M}^{00}=\mathcal{U}_{M} \cap \mathcal{U}^{00}\right)$;

(iii) $\int_{0}^{\tau}\left\|U_{1}^{t}\right\|_{\mathcal{L}\left(\mathcal{U}^{1} ; \mathcal{U}_{M}^{1}\right)} d t<\infty \forall \tau \in \mathbb{R}_{+}$.

Then there exists a unique solution of (4), which is a quasi-stationary semi-trajectory of equation (4).

Now let $\mathcal{U}_{k}$ and $\mathcal{F}_{k}$ be Banach spaces, operators $A_{k} \in \mathcal{L}\left(\mathcal{U}_{k}, \mathcal{F}_{k}\right)$, and operators $B_{k}$ : $\operatorname{dom} B_{k} \rightarrow \mathcal{F}$ be linear and closed with domains dom $B_{k}$ dense in $\mathcal{U}_{k}, \quad k=1,2$. Construct spaces $\mathcal{U}=\mathcal{U}_{1} \times \mathcal{U}_{2}, \quad \mathcal{F}=\mathcal{F}_{1} \times \mathcal{F}_{2}$ and operators $L=A_{1} \otimes A_{2}, \quad M=B_{1} \otimes B_{2}$. By construction operator $L \in \mathcal{L}(\mathcal{U} ; \mathcal{F})$, and operator $M$ : dom $M \rightarrow \mathcal{F}$ is linear, closed and densely defined, in $\mathcal{U} \operatorname{dom} M=\operatorname{dom} B_{1} \times \operatorname{dom} B_{2}$.

Theorem 3. Let the operators $B_{k}$ be strongly $\left(A_{k}, p_{k}\right)$-sectorial, $k=1,2$; and $p_{1} \geq p_{2}$. Then the operator $M$ is strongly $\left(L, p_{1}\right)$-sectorial. 


\section{The Existence of the Unique Solution}

Following [2] consider problem (2), (3) for system (1) transformed to the form

$$
\begin{gathered}
(1-\chi \triangle) v_{t}=\nu \triangle v-(v \cdot \nabla) v-\frac{1}{\rho} \nabla p-2 \Omega \times v+\frac{1}{\rho \mu}(\nabla \times b) \times b+f^{1}, \\
\nabla(\nabla \cdot v)=0, \quad \nabla(\nabla \cdot b)=0, \quad b_{t}=\delta \triangle b+\nabla \times(v \times b)+f^{2} .
\end{gathered}
$$

Then similarly to [2] we introduce the spaces $\mathcal{U}$ and $\mathcal{F}$, the operators $L$ and $M$ generated by the problem (2), (3) for the transformed system (1). Strong $(L, 1)$ sectorialness of the operator $M$ under the assumption $\chi^{-1} \notin \sigma(A), A=\nabla^{2} E_{n}$ ( $E_{n}$ is identity $n \times n$ matrix) is established using the Theorem 3. The form of the nonlinear operator $F$ is similar to the one in [2], only the first and the second elements of the vectorcolumn include the term $f^{1}$, and the last element includes $f^{2}$. Belonging of $F$ to the class $C^{\infty}\left(\mathcal{U}_{\mathcal{M}} ; \mathcal{F}\right)$ is proved by calculation of the Frechet derivatives of this operator. Therefore, all assumptions of Theorem 1 and Theorem 2 are satisfied. Consequently, the following result holds.

Theorem 4. If $\varkappa^{-1} \notin \sigma(A) \cup \sigma\left(A_{\sigma}\right)$, then for all $u_{0} \in \mathfrak{M}$ and some $T \in \mathbb{R}_{+}$there exists a unique solution $u=\left(u_{\sigma}, 0, u_{p}, u_{b}\right)$ of $(1)$ - (3) which is a quasi-stationary trajectory. Moreover, $u(t) \in \mathfrak{M}$ for all $t \in(0, T)$.

Here $A_{\sigma}$ is a restriction of the operator $A$ on the corresponding subspace of solenoidal vectors. $u_{\sigma}, 0, u_{p}, u_{b}$ are the elements of the corresponding subspaces of Banach space $\mathcal{U}$ [2]; $\mathfrak{M}$ is the extended phase space of (1), (3), which has the following form

$$
\mathfrak{M}=\left\{u \in \mathcal{U}_{M}: u_{\pi}=0, b_{\pi}=0, u_{p}=\Pi\left(\nu A_{\sigma}-\left(u_{\sigma} \cdot \nabla\right) u_{\sigma}-2 \Omega \times u_{\sigma}+\left(\nabla \times b_{\sigma}\right) \times b_{\sigma}+f^{1}\right)\right\}
$$

\section{Computational Experiment}

Introduce a cylindrical coordinate system $(r, \varphi, z)$ with center $O$ on one side of the surface of the cylinder $D$ and combine $O z$ axis with the cylinder axis. In the future, we will assume that a flow of fluid is axially symmetric.

Figures $1-3$ show the charts of surfaces of fluid flow velocity components at time $t^{*}=2 \mathrm{~s}$, obtained for the following values of the problem parameters: $\chi=2,7 \mathrm{~m} / \mathrm{s}^{2}$, $\nu=0,00328 \mathrm{~m}^{2} / \mathrm{s}, \mu=1 \rho=1000 \mathrm{~kg} / \mathrm{m}^{3}, \delta=0,1, r_{0}=0,1 \mathrm{~m}, z_{0}=0,2 \mathrm{~m}$. Vector-functions' components $f^{1}, f^{2}$ had the form $f_{r}^{1}=0,001 r\left(r_{0}-r\right) \sin (\pi t) \mathrm{kg} \cdot \mathrm{m} / \mathrm{s}^{2}$, $f_{\varphi}^{1}=f_{z}^{1}=0, f_{r}^{2}=0,001 r \cos (\pi t) \mathrm{T}, f_{\varphi}^{2}=f_{z}^{2}=0$. Vector functions $v_{0}(r, z)$ and $b_{0}(r, z)$ in the initial conditions (2) are given in the form $v_{0}=\omega_{0} r i_{r}, b_{0}=b_{r_{0}} i_{r}$, where $\omega_{0}=0,251 / \mathrm{s}$, $b_{r_{0}}=0,00005 \mathrm{~T}$. The initial conditions for vector-functions $\psi, A$ are given in the form: $\psi(r, z, 0)=0,25 \omega_{0} r\left(2 z i_{r}-r i_{z}\right), A(r, z, 0)=-b_{r_{0}} z i_{\varphi}$. The boundary and initial conditions for vector-functions $\psi$ and $A$ are given in the form: $\psi(r, z, t)=0, A(r, z, t)=0$, $(x, r, t) \in \partial D \times \mathbb{R}_{+}$.

Conducted computational experiments show a computational stability and computational efficiency of the developed algorithm for numerical solution of initialboundary problem $(1)-(3)$. 


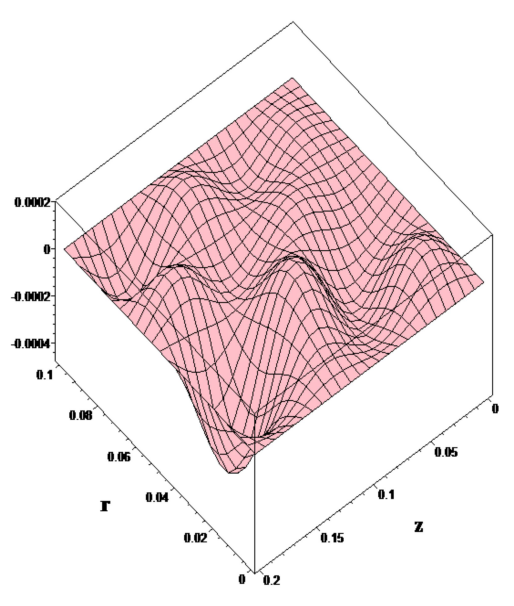

Fig. 1. Chart of surface radial component of fluid flow velocity $v_{r}=v_{r}\left(r, z, t_{*}\right)$

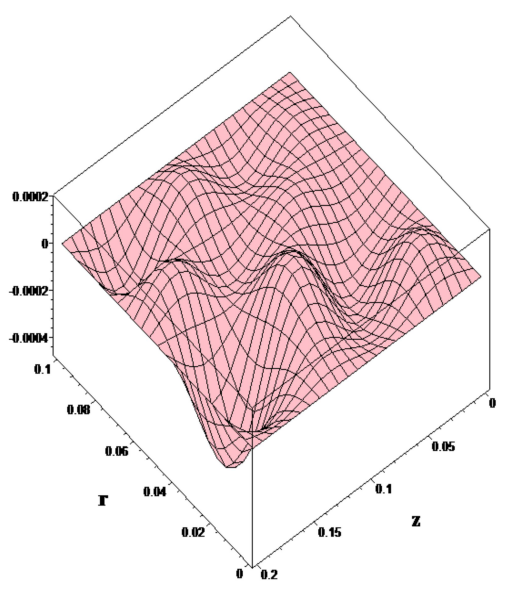

Fig. 2. Chart of surface transversal component of fluid flow velocity $v_{\varphi}=v_{\varphi}\left(r, z, t_{*}\right)$

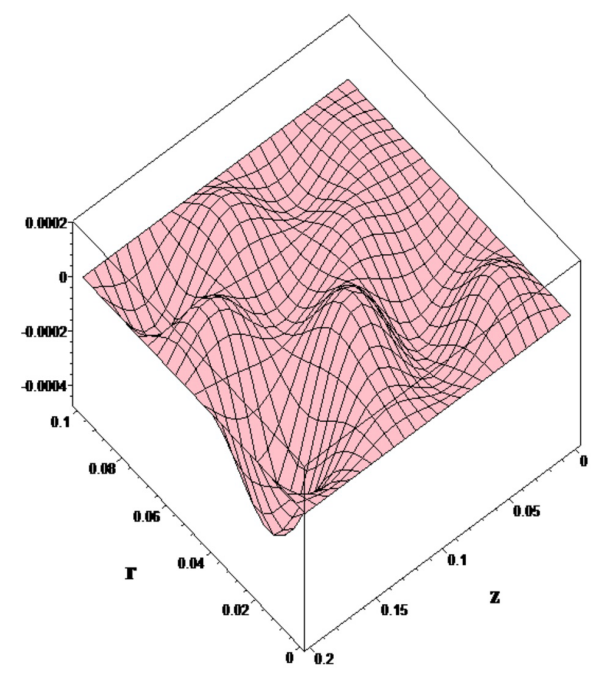

Fig. 3. Chart of surface axial component of fluid flow velocity $v_{z}=v_{z}\left(r, z, t_{*}\right)$ 


\title{
References
}

1. Hide R. On Planetary Atmospheres and Interiors. Mathematical Problems in the Geophisical Sciences, American Mathematical Society, 1971.

2. Sukacheva T.G., Kondyukov A.O. Phase Space of a Model of Magnetohydrodynamics. Differential Equations, 2015, vol. 51, no. 4, pp. 502-509. DOI: 10.1134/S0012266115040072

3. Kadchenko S.I., Kondyukov A.O. Numerical Study of a Flow of Viscoelastic Fluid of Kelvin - Voigt Having Zero Order in a Magnetic Field. Journal of Computational and Engineering Mathematics, 2016, vol. 3, no. 2, pp. 40-47. DOI: $10.14529 /$ jcem1602005

4. Sukacheva T.G., Kondyukov A.O. On a Class of Sobolev Type Equations. Bulletin of the South Ural State University. Series: Mathematical Modelling, Programming and Computer Software, 2014, vol. 7, no. 4, pp. 5-21. DOI: 10.14529/mmp140401

5. Kondyukov A.O., Kadchenko S.I., Kakushkin S.N. Numerical Modelling of the Motion of the Viscoelastic Conductive Fluid in the Magnetic Field. The copyright holder: Federal state budgatary educational institution of higher education "Yaroslav-the-Wise Novgorod State University" (RU), №2016619268, registered 17.08.2016, the registry of computer programs.

Received 24 December, 2016

УДК 517.9

DOI: $10.14529 / \mathbf{m m p} 170110$

\section{ВЫЧИСЛИТЕЛЬНЫЙ ЭКСПЕРИМЕНТ ДЛЯ ОДНОГО КЛАССА МАТЕМАТИЧЕСКИХ МОДЕЛЕЙ МАГНИТОГИДРОДИНАМИКИ}

\author{
А.О. Кондюков, Т.Г. Сукачева, С.И. Кадченко, Л.С. Рязанова
}

\begin{abstract}
Исследуется первая начально-краевая задача для системы уравнений, моделирующей движение несжимаемой вязкоупругой жидкости Кельвина - Фойгта в магнитном поле Земли с учетом внешнего воздействию на жидкости. Задача изучается в предположении, что жидкость находится под влиянием различньх внешних воздействий, зависящих не только от координаты точки в пространстве, но и от времени. В рамках теории полулинейных неавтономных уравнений соболевского типа доказана теорема о существовании и единственности решения, которое является квазистационарной полутраекторией, а также дано описание расширенного фазового пространства. Приведены результаты вычислительного эксперимента

Ключевые слова: магнитогидродинамика; уравнения соболевского типа; расширенное фазовое пространство; несжимаемая вязкоупругая жидкость; явные одношаговые формулы Рунге - Кутты.
\end{abstract}

\section{Литература}

1. Hide, R. On Planetary Atmospheres and Interiors / R. Hide // Mathematical Problems in the Geophysical Sciences. - American Mathematical Society, 1971.

2. Сукачева, Т.Г. Фазовое пространство одной модели магнитогидродинамики / Т.Г. Сукачева, А.О. Кондюков// Дифференциальные уравнения. - 2015. - Т. 51, № 4. - С. 495-501.

3. Kadchenko, S.I. Numerical Study of a Flow of Viscoelastic Fluid of Kelvin - Voigt Having Zero Order in a Magnetic Field / S.I. Kadchenko, A.O. Kondyukov // Journal of Computational and Engineering Mathematics. - 2016. - V. 3, № 2. - P. 40-47. \& Computer Software (Bulletin SUSU MMCS), 2017, vol. 10, no. 1, pp. 149-155 
4. Sukacheva T.G. On a Class of Sobolev Type Equations / T.G. Sukacheva, A.O. Kondyukov // Вестник ЮУрГУ. Серия: Математическое моделирование и программирование. 2014. - T. 7, № 4. - C. 5-21.

5. Численное моделирование течения вязкоупругой электропроводной жидкости в магнитном поле / Кондюков А.О., Кадченко С.И., Какушкин С.Н.; правообладатель: ФГБОУ ВО «Новгородсикй государственный университет имени Ярослава Мудрого».№2016619268, зарегистр. 17.08.2016, реестр программ для ЭВМ.

Алексей Олегович Кондюков, аспирант, кафедра алгебры и геометрии, Новгородский государственный университет имени Ярослава Мудрого (г. Великий Новгород, Российская Федерация), k.a.o_leksey999@mail.ru.

Тамара Геннадьевна Сукачева, доктор физико-математических наук, професcop, кафедра алгебры и геометрии, Новгородский государственный университет имени Ярослава Мудрого (г. Великий Новгород, Российская Федерация), tamara.sukacheva@novsu.ru.

Сергей Иванович Кадченко, доктор физико-математических наук, профессор, кафедра прикладной математики и информатики, Магнитогорский государственный технический университет им. Г.И. Носова (г. Магнитогорск, Российская Федерация), kadchenko@masu.ru.

Любовь Сергеевна Рязанова, кандидат педагогических наук, доцент, кафедра прикладной математики и информатики, Магнитогорский государственный технический университет им. Г.И. Носова (г. Магнитогорск, Российская Федерация), ryazanova2006@ramber.ru.

Поступила в редакиию 24 декабря 2016 г. 